INTERNATIONAL JOURNAL OF RESEARCHES IN BIOSCIENCES, AGRICULTURE AND TECHNOLOGY (c) VISHWASHANTI MULTIPURPOSE SOCIETY (Global Peace Multipurpose Society) R. No. MH-659/13(N) www.ijrbat.in

\title{
CHEMICAL ANALYSIS OF SUMMER HONEYS COLLECTED FROM APISDORSATA HIVES OF NAGBHID TAHSIL OF CHANDRAPUR DISTRICT OF MAHARASHTRA STATE (INDIA)
}

\author{
Borkar Laxmikant ${ }^{*}$ and Mate Devendra² \\ ${ }_{1}$ Department of Botany, S. S. Jaiswal Arts, Comm. and Science College, Arjuni (Mor), Gondia, India. \\ 2Department of Botany, NutanAdarsh Arts, Commerce and M. H. Wegad Science College, Umrer, Dist - \\ Nagpur. \\ *Corresponding Author E-mail :borkarlaxmikant@rediffmail.com
}

\begin{abstract}
:
The present investigation was undertaken to determine the chemical analysis of two honey samples were collected from forest area of village Girgoan and Kachepar of Nagbhid Tahsil, District Chandrapur, Maharashtra State (India) in summer. These samples were analysed for several parameters such as moisture, total reducing sugar, Levulose or Fructose, Dextrose or Glucose, L/D ratio, Sucrose, Acidity. This type of chemical analysis favours the utilization of the honey for good quality in this area.
\end{abstract}

Keywords: Chemical Analysis, Summer Honey, Nagbhid Tahsil.

\section{INTRODUCTION:}

Honey is a carbohydrate rich naturally complex product produced by honey bees from floral nectar. Honey has been used by all civilizations as nutrient food and in traditional medicine. The quality of honey depends on various physiological factors such as climate, soil, etc. Honey contains Sugar, Protein, Moisture, Vitamins, Minerals, Enzymes, Polyphenols and Flavonnoids (Manary et al., 2002) because of this unique complex nature, honey is proved to be useful in the treatment of burns, wounds, skin ulcers as an antioxidant and iin the treatment of external eye diseases (Balasubramanyam, 2011). Furthermore, honey is a highly valuable ingredient in condiments, beverage, sauces and sweets. In fact numerous studies have been reported on physical, chemical and melissopalynological parameter of honeys from all over the world. (Adenken et al., 2010; Anklam, 1998; Cherian et al., 201; Borkar Laxmikant and Mate Devendra, 2014; Downey et al., 2005; Ramnathnad Shivaramm, 2012, Terrab et al., 2002; Xesus et al., 2010). The scientific literature revealed that the information is not available with respect to chemical characteristics of honeys collected from forest area of village Giroan and Kachepar which are located in Nagbhid Tahsil of Chandrapur District, Maharashtra State (India). The purpose of this study has to investigate some chemical parameters viz. Content of Moisture, Total Reducing Sugar, Levulose or Fructose, Dextrose or Glucose, Levulose/Dextrose, Sucrose, Acidity of honey.

\section{METHOD AND MATERIAL:}

Chemical analysis of the honeys are carried out by using Indian Standard Specification, IS: 4941 (1974) and IS: 8464 (1977). The percentage of Total Reducing Sugar, (Levulose or Fructose + Dextrose or Glucose), Levulose, Dextrose, Sucrose, Acidity, Moisture and L/D ratio were estimated.

\section{RESULT AND DISCUSSION:}

The chemical properties of honey samples collected from the two different places Viz. Girgoan and Kachepar in summer, from Nagbhid Tahsil of Chandrapur District of Mahartashtra State are reported in table no. 1 .

In the present study moisture content in the sample ranges from $24.8-30$

Increase in the temperature moisture is low and decrease the temperature moisture is high. Increase in moisture content of honey is also indicative of adulteration. The low moisture content of honey forms an important part of the system which protect honey from attack by microorganism.

\section{Sugars:}

Honey consists of mostly Glucose and Fructose. The actual proportion of Fructose to Glucose in any particular honey depends largely on the sources of the nectar. All samples contained more Fructose than Glucose.

Acidity:

Acidity of the honey sample ranges by 0.2323 to 0.2875 respectively. 


\section{CONCLUSIONS:}

Honey collected from these two places is rich in fructose. Fructose level in honey is higher than that of Glucose. This indicated that Nagbhid honeys would be less prone to granulation. . Honey with high Fructose to Glucose ratio would remain liquid for longer period. The Fructose/Glucose ratios may have an impact or honey flavour, since fructose is much sweeter than glucose and due to more content of fructose and sucrose it is beneficial for diabetic patients. Acidity values may indicative the fermentation of honey sugar by yeast.

\section{REFERANCE :}

Adenekan, MO, Amusa NA, Lawal AO, Okpeze VE.

Physicochemical and microbiological properties of honey samples obtained from Bada, Journal

of Microbiology and Antimicrobials, 2010; 2(8):100-104

Al ML, Danial DJ, Moise A, Bebis O, Lasio L, Bogedanov S.

Phycochemical and bioachive properties of different floral originhoneys from Romdnia. Food Chemistry, 2002; 112, 863-867.

Anklam EA. A review of the analogical and botanical origine of honey, Food Chemistry, 1998; 63, $549-562$.

Balsubramanyam MV. Chemical Characteristics of much floral wild and apiary honeys from Western Ghats of Karnataka. The Bioscan, 2011: 6, $467-469$.

BorkarLamikant and Mate Devendra. Chemical Analysis of Summer Honeys collected from Apisdoersata hives of BhadrawatiTahsil of Chandrapur District of Maharashtra State (India), Int. Res. J. of Sci. \&Engg., 2014: 2 (4):139_141.

Cherian KJ Bhowal M and Godghate SD. Pollen and hysiochemical analysis of honey preduceed by Apiscerenaindica of Nagpur, Maharashtra (INDIA). Journal of Environmental Research and Development, 2011; 5(3): 542-550.

Downey GJ, Hussey K, Kelly JD, Walshe TF and Martin PG. Preliminary contribution to the characteristics of artisanal honey produced on the island of Ireland by palynological and physico - chemical data. Food Chemistry, 2005; 91, 347-354.

IS: 4941-1974 Indian Standard Specification for extracted honey (First Revision), Indian Standards Institution, 1974, New Delhi : 1-16.

IS: 8464-1977 Indian Standard Specification for Squeezed honey, Indian Standards Institution, 1977, New Delhi : 1-8.

RamnathSubharani and Venkataramegouda Sivaramm. physicochemical and pollen analysis of Western ghats honey of Karnataka south, India. I.J. S.N.,2012: 3(4):831- 835

Terrab AJ, Diez MJ and Heredia FJ. Characterization of Moroccan unifloral honeys by theis physicochemical characteristics. Food Chemistry, 2002: 79, 373 - 379.

Xesus FJ, Jose P, Maria LE, Antonio I and Jose PA. Palynological and physicochemical data charctrazation of honeys produced in the Entre - Douro e Munho region of Portugal, International Journal of food Science and Technology, 2010; 45,: 1255-1262. 
Table no. 1: Chemical Analysis of honey samples collected from two different places of NagbhidTahsil of Chandrapur District.

\begin{tabular}{|c|c|c|c|c|c|c|c|c|}
\hline \multirow[b]{2}{*}{ Sr.No. } & \multirow[b]{2}{*}{$\begin{array}{l}\text { Location of } \\
\text { sample }\end{array}$} & \multicolumn{7}{|c|}{ Parameter (\%) } \\
\hline & & Moisture & $\begin{array}{l}\text { Total } \\
\text { Reducing } \\
\text { Sugar }\end{array}$ & $\begin{array}{l}\text { Levulose } \\
\text { (Fructose) }\end{array}$ & $\begin{array}{l}\text { Dextrose } \\
\text { (Glucose) }\end{array}$ & $\begin{array}{l}\text { L/D } \\
\text { Ratio }\end{array}$ & Sucrose & Acidity \\
\hline 1 & CHN-NAG-GIR & 24.8 & 71.681 & 39.592 & 32.189 & 1.303 & 2.545 & 0.2323 \\
\hline 2 & CHN-NAG-KAC & 30 & 73.652 & 38.312 & 35.340 & 1.204 & 2.667 & 0.2875 \\
\hline
\end{tabular}

